\title{
Emerging Competition and Risk-Taking Incentives at Fannie Mae and Freddie Mac
}

\author{
W. Scott Frame* \\ Research Department \\ Federal Reserve Bank of Atlanta \\ 1000 Peachtree Street NE \\ Atlanta GA 30309 \\ Tel: 404-498-8783 \\ Fax: 404-498-8810 \\ e-mail:scott.frame@atl.frb.org \\ Lawrence J. White* \\ Stern School of Business \\ New York University \\ 44 West $4^{\text {th }}$ Street \\ New York, NY 10012-1126 \\ Tel: 212-998-0880 \\ Fax: 212-995-4218 \\ e-mail:lwhite@stern.nyu.edu
}

\begin{abstract}
$\underline{\text { Abstract }}$
This paper examines two major forces that may soon increase competition in the U.S. secondary conforming mortgage market: 1) the expansion of Federal Home Loan Bank mortgage purchase programs, and 2) the adoption of revised risk-based capital requirements for large U.S. banks (Basel II). We argue that this competition is likely to reduce the growth and relative importance of Fannie Mae and Freddie Mac and hence their franchise values and effective capital. Such developments could, in turn, lead to more risky behaviors by these two GSEs. It is this last consequence that warrants greater regulatory awareness.

JEL Classification Numbers: G21, G28

Keywords: Government-sponsored enterprises, mortgages, securitization, risk-based capital, moral hazard, charter value

*The views expressed in this paper do not necessarily reflect those of the Federal Reserve Bank of Atlanta, the Federal Reserve System, or their staffs. During 1986-1989 White was a member of the Federal Home Loan Bank Board, with responsibilities that included being a board member of Freddie Mac and overseeing the Federal Home Loan Bank System. We would like to thank Matthew Green, Anjela Kniazeva, Diana Kniazeva, and Heather Zackal for their research assistance and for valuable comments on an earlier draft. Michael Fratantoni, Joseph McKenzie, Wayne Passmore, Larry Wall, and seminar participants at the 2004 ASSA meetings provided additional comments.
\end{abstract}




\section{Emerging Competition and Risk-Taking Incentives at Fannie Mae and Freddie Mac}

\section{Introduction}

The Federal National Mortgage Association (Fannie Mae) and the Federal Home Loan Mortgage Corporation (Freddie Mac) dominate the U.S. secondary market for conforming singlefamily residential mortgages as both investors in and securitizers of these loans. ${ }^{1}$ For example, in 2002, these two government-sponsored enterprises (GSEs) acquired the credit risk on \$1.5 trillion in conforming mortgages, or 78 percent of the $\$ 1.9$ trillion in conforming mortgage originations that year. ${ }^{2}$ Such activity over the past decade or so has resulted in Fannie Mae and Freddie Mac becoming the second and fourth largest U.S. companies, respectively, when ranked by total assets as of year-end 2002.

As GSEs, Fannie Mae and Freddie Mac have federal charters ${ }^{3}$ that include provisions that serve to lower their operating costs directly (e.g., state and local income tax exemptions) as well as create the perception that their obligations have implicit federal backing (due to, among other things, having access to a line of credit with the Treasury). ${ }^{4}$ The presence of such federal benefits naturally

\footnotetext{
${ }^{1}$ Conforming single-family residential mortgages are those with balances below the legal limits on the size of mortgages that Fannie Mae and Freddie Mac can buy. For single-family mortgage loans, the conforming loan limit was $\$ 300,700$ in 2002,\$322,700 in 2003, and is \$333,700 in 2004.

2 These figures were computed using data contained in Inside Mortgage Finance (2003a, 2003b) and reflect conventional and government guaranteed loans (both fixed- and adjustable-rate), but not "jumbo" or “subprime” loans.

${ }^{3}$ Unlike almost all other U.S. corporations, which are incorporated under a specific state's corporation law, Fannie Mae and Freddie Mac were specifically created and chartered by acts of Congress. Their charter acts can be accessed at http://www.ofheo.gov/Media/Archive/docs/reports/fnma.pdf (Fannie Mae) and http://www.ofheo.gov/Media/Archive/docs/reports/freddie.pdf (Freddie Mac), respectively.

${ }^{4}$ By law, GSE securities are required to include language indicating that they are not guaranteed by, or otherwise an obligation of, the federal government. However, past government actions suggest otherwise. During the late 1970s and early 1980s, Fannie Mae was insolvent on a market value basis and benefited from supervisory forbearance. Also, in the late 1980s, the Farm Credit System (another GSE) required a taxpayer bailout totaling \$4 billion. The U.S. General Accounting Office (1990, 90-91) discusses both of these episodes, while Kane and Foster (1986) provide estimates of the degree of insolvency for Fannie Mae during its financial distress.
} 
leads to questions about their purpose, size, and distribution. That is, should the federal government support housing finance through GSEs? and if so, how they should be structured so as to maximize social benefit and minimize taxpayer risk? Indeed, public interest in these issues has recently been heightened in the wake of hedging and accounting travails at Fannie Mae and Freddie Mac (Frame and White, 2004).

Like the mortgage interest deduction and a myriad of other governmental policies, Fannie Mae and Freddie Mac are a mechanism by which the federal government encourages the construction and consumption of housing. ${ }^{5}$ While such encouragements do provide benefits for households in their roles as buyers and consumers of housing services, these benefits are not free. The encouragements for housing significantly reduce the resources available for and thus impose costs on the other sectors of the economy (e.g., Mills 1987; Taylor 1998). Further, it's unclear that that federal sponsorship of Fannie Mae and Freddie Mac actually has a material impact on homeownership rates (Feldman, 2003). As a result, Calomiris (2001) and White (2003) argue that Fannie Mae and Freddie Mac should be fully privatized and replaced with targeted explicit subsidies for first-time, low- and moderate-income homebuyers. Such subsidies, the authors argue, would be more effective in dealing with the genuine positive externality that accompanies home ownership and would be less distortionary.

The size of Fannie Mae’s and Freddie Mac’s obligations raises questions about the extent of potential taxpayer liability, systemic risk exposure, and the appropriate safety and soundness regulatory regime for GSEs. As of year-end 2002, Fannie Mae had total assets totaling almost \$890 billion and net off-balance sheet mortgage guarantees of over \$1.0 trillion, while Freddie Mac had about $\$ 720$ billion in total assets and net off-balance-sheet mortgage guarantees of over $\$ 740$ billion. ${ }^{6}$ Furthermore, both of these enterprises are highly leveraged, with ratios of total equity

\footnotetext{
${ }^{5}$ Specifically, the charter benefits reduce the GSEs' operating and funding costs; and, in turn, these enterprises are expected to pass these savings on to borrowers.

${ }^{6}$ To avoid double counting, the figures for off-balance-sheet mortgage guarantees for Fannie Mae and Freddie Mac are
} 
capital to total assets of 3.2 percent and 3.3 percent, respectively, at year-end 2002. With their large absolute sizes and their comparatively thin capital ratios, if either Fannie Mae or Freddie Mac were to experience serious financial difficulties, the financial markets (especially those that are involved in housing finance) would likely be rattled. ${ }^{7}$ As a consequence of potential taxpayer risks, the Congress created the Office of Federal Housing Enterprise Oversight (OFHEO) in 1992 as the exclusive safety-and-soundness regulator for Fannie Mae and Freddie Mac. ${ }^{8}$

Estimating the distribution of benefits channeled through Fannie Mae and Freddie Mac is also important in evaluating the efficiency of government sponsorship. For example, the U.S. Congressional Budget Office (2001) estimates that, for 2000, the gross benefits accruing to Fannie Mae and Freddie Mac were $\$ 10.6$ billion, the net benefit to homebuyers through lower mortgage rates from the two firms was $\$ 6.7$ billion, and the residual benefit to Fannie Mae and Freddie Mac shareholders was $\$ 3.9$ billion. ${ }^{9}$ Such estimates are consistent with the observation that Fannie Mae and Freddie Mac are highly profitable financial institutions that regularly post annual return on assets near 25 percent. $^{10}$ By contrast, industry ROE for all FDIC-insured commercial banks

net of the mortgage-backed securities that are held on balance sheet. Recent financial information for Freddie Mac is subject to revision because of an ongoing earnings restatement.

\footnotetext{
${ }^{7}$ For a discussion of systemic risk issues with respect to Fannie Mae and Freddie Mac, see U.S. Office of Federal Housing Enterprise Oversight (2003b) and Fahey (2003).
}

\footnotetext{
${ }^{8}$ The Federal Housing Enterprises Financial Safety and Soundness Act of 1992 established OFHEO as part of the Department of Housing and Urban Development (HUD). Prior to this, HUD maintained broad regulatory oversight responsibilities for Fannie Mae. Prior to the passage of the Financial Institutions Reform, Recovery and Enforcement Act (FIRREA) of 1989, Freddie Mac was the responsibility of the Federal Home Loan Bank Board (FHLBB). Between 1989 and 1992, responsibility for overseeing Freddie Mac lay with HUD.
}

\footnotetext{
${ }^{9}$ See Fannie Mae (2001), Freddie Mac (2001), Toevs (2001), and Pearce and Miller (2001) for various criticisms of the CBO study.

${ }^{10}$ Fannie Mae has posted annual return on equity (ROE) figures exceeding 25 percent for each of the years 1998-2002, while Freddie Mac's average annual ROE was only slightly lower (24.2 percent) during the same period (U.S. Office of Federal Housing Enterprise Oversight, 2003a). For a longer period of 15 years (1988-2002), Fannie Mae’s ROE has averaged 27.5 percent, while Freddie Mac’s averaged 23.5 percent.
} 
averaged 14 percent during the 1998-2002 period. $^{11}$

The benefit distribution estimates and profitability are also consistent with Fannie Mae and Freddie Mac enjoying some market power in the secondary conforming-conventional mortgage market as a result of natural barriers to entry arising from their GSE status (Goodman and Passmore 1992; Hermalin and Jaffee, 1996). ${ }^{12}$ It is widely recognized that Fannie Mae and Freddie Mac -- as conduits for a federal mortgage subsidy -- serve to lower interest rates below that which the private market would otherwise provide. ${ }^{13}$ Market power in this context then reflects the difference between observed mortgage interest rates and those that would be predicted based on the existence of a fully efficient (and competitive) subsidy pass-though mechanism by the low-cost producers. ${ }^{14}$

On the assumption that Fannie Mae and Freddie Mac will continue to operate in the housing finance sector and that the goal of lowering housing finance costs should continue to be pursued, governmental policies should be adopted that encourage these entities to maximize benefits to homebuyers while also minimizing taxpayer risk. A frequent reform suggestion is that mortgage borrowers could receive more of the GSE benefits if competition in the secondary conforming

\footnotetext{
${ }^{11}$ An alternative profitability ratio, return on assets (ROA), is substantially lower for the two GSEs than that for commercial banks. The primary reason for this is that the GSEs are far more leveraged. As an indicator of likely rents from less-than-completely-vigorous competition, ROE is the superior measure.

${ }^{12}$ Hermalin and Jaffee (1996) contend that legal distinctions divide the secondary mortgage market into three pieces: FHA/VA, conforming-conventional, and jumbo. Fannie Mae (1996) argues that this market definition is incorrect and that the appropriate market encompasses all mortgages that are below the conforming loan limit in both the primary and secondary markets.

${ }^{13}$ See Hendershott and Shilling (1989), Ambrose and Warga (1996, 2001), Cotterman and Pearce (1996), U.S. Congressional Budget Office (2001), and McKenzie (2002).

${ }^{14}$ Theory predicts that Fannie Mae and Freddie Mac (if they explicitly or implicitly coordinated their behavior) would set prices such that, on the margin, entry would be unprofitable and hence would be deterred. This is known as a "limit pricing strategy" (e.g., Bain, 1956; Tirole, 1988). The observed partial pass-through of the GSEs' benefits presented in U.S. Congressional Budget Office (2001) could well be an indication of their exercise of market power in this way. However, as White (1996) points out, partial pass-through could (as a theoretical matter) also arise from completely competitive (e.g., Bertrand) behavior by the GSEs, if they were both subject to diseconomies of scale and thus faced a rising marginal cost curve at their observed levels of operations. Also, it is well understood that even Bertrand rivals, if they sell differentiated products (i.e., that price is not the sole consideration for buyers when they choose among sellers), can earn rents.
} 
mortgage market were heightened. However, an important point of our analysis is that, along with the more complete transmission of the GSEs' benefits to mortgage buyers, increased competition would also create incentives for the GSEs to engage in greater risk-taking and thereby place taxpayers at greater risk. Thus, the speed at which competition is introduced to the secondary market and the ability of regulators effectively to monitor risk profiles of the GSEs are important elements to consider in any reform proposal.

In the remainder of this paper, we discuss two potential sources of heightened competition to Fannie Mae and Freddie Mac -- neither of which requires new legislation. These are: 1) the Federal Home Loan Banks' mortgage purchase programs; and 2) the revised risk-based capital requirements (Basel II) that will apply to large commercial banks. While both mechanisms for increased competition could potentially increase the transmission of the GSE benefits, they could also bring a potential downside: an increase in the risk-taking incentives of Fannie Mae and Freddie Mac. This paper analyzes this potential for greater risk-taking in the context of the extant literature. Before doing this, however, we outline the overall landscape in the secondary conforming mortgage market.

\section{The Landscape}

Homebuyers obtain financing for their homes through mortgage lenders, typically depository institutions or mortgage banks, ${ }^{15}$ in the primary mortgage market. Primary mortgage lenders, in turn, decide whether and how to hold these financial assets. The lender may hold the mortgages as "whole loans" on its balance sheet; the lender may swap mortgages for mortgage-backed securities (which can be held as assets on its balance sheet, or can be sold in the secondary market); or the lender can sell the mortgage assets outright. It is the latter two areas where Fannie Mae and Freddie

\footnotetext{
${ }^{15}$ By "mortgage banks", we mean entities that originate mortgages and then sell them quickly to another entity and thus do not hold them as assets on their own balance sheets for any significant amount of time. In many instances, these mortgage banks will have "pre-sold" the mortgages through forward contracts.
} 
Mac enter the picture. ${ }^{16}$

Fannie Mae and Freddie Mac acquire mortgage credit (default) risk through a swap program and a cash program. First, under the swap program, a lender selects and pools a group of mortgages and swaps them for mortgage-backed securities (MBS) that are issued and guaranteed by Fannie Mae or Freddie Mac. These "simple" securities represent an undivided interest - the right to receive the interest payments (less a fee) and the repayments of principal -- in the same pool. ${ }^{17}$ Financial intermediaries (e.g., commercial banks and other depositories) that would otherwise be inclined to hold their mortgage loans in their asset portfolios use the swap program. Second, under the cash program, Fannie Mae and Freddie Mac simply purchase mortgage loans from lenders (e.g., mortgage banks) in exchange for cash. Subsequently, the GSEs may elect to pool some of these mortgages as collateral for an MBS offering or simply hold the loans in their portfolios as an investment.

The swap program allows a mortgage lender to shed the credit risk associated with a pool of mortgages in exchange for the lender's paying an annual fee to Fannie Mae or Freddie Mac, which is on the order of 20 basis points of the outstanding principal balance of the loan pool. The annual fee - commonly known as a "guarantee fee" - represents a payment to the GSEs for their assumption of the credit risk on the pool of mortgages; and thus for the GSEs' guarantee of the timely payment of interest and principal to MBS holders. This swap program also takes advantage of a significant reduction in the risk-based capital requirements that apply to depository institution lenders.

For depository institutions concerned with managing their required risk-based capital, the differential treatment of residential mortgages (which have a 4\% capital-to-assets requirement) and

\footnotetext{
${ }^{16}$ Broad descriptions of Fannie Mae and Freddie Mac and their backgrounds and activities can be found, among other places, in Weicher (1994), Frame and Wall (2002), and White (2003). The companies' self-descriptions can be found on their websites: www.fanniemae.com and www.freddiemac.com.

${ }^{17}$ More complicated securities structures are also possible, whereby various parts of the payment stream from the securities are parceled out to separate claimants.
} 
mortgage-backed securities (which, for MBS that are AA-rated or better, have a 1.6\% capital requirement) creates an incentive for these institutions to securitize conforming mortgages, since securitization allows them to free up capital. This can be illustrated by a simple example in which a lender holds a \$25 million pool of 30-year fixed-rate loans with a 7.00 percent interest rate. The lender may either 1) hold \$1 million of capital against the \$25 million in loans earning 7.00 percent interest, or 2) hold $\$ 400,000$ in capital against \$25 million in GSE mortgage-backed securities that earn 6.80 percent. $^{18}$ Thus, in return for replacing a higher-risk asset (that includes credit risk) that earns 7.00 percent, with a lower-risk asset (that is free of credit risk) that earns $6.80 \%$, the lender could free up $\$ 600,000$ in capital through securitization. ${ }^{19}$ This type of activity is commonly referred to as "regulatory capital arbitrage" (Jones, 2000).

The cash program allows the lender to avoid all of the credit and interest rate risk (as well as avoiding the funding costs) associated with the loan pool because the lender simply sells the loans (while still collecting certain loan origination fees). Under either the swap or cash programs, a lender can continue to service the loans (i.e., collect and forward the borrowers' monthly payments and deal with any delinquencies) and earn about 25 basis points for this service.

The ability to purchase or securitize mortgages is not unique to Fannie Mae and Freddie Mac. Other financial institutions, such as large commercial banks, mortgage banks, and securities firms, also securitize residential mortgages (although their securitization activity is largely confined to non-conforming mortgages -- i.e., "jumbo" and "subprime" loans). Also, active secondary markets and securitization activity pervade the rest of the consumer credit market, such as the areas

\footnotetext{
${ }^{18}$ The reduction in the interest rate from 7.00 percent to 6.80 percent interest rate reflects a 20 basis points guarantee fee. Further, the actual coupon on the mortgage security would be 6.55 percent, but the lender would earn an additional 0.25 percent from servicing (as is discussed in the text below).

${ }^{19}$ The $\$ 600,000$ could be invested (with a 1.6\% capital requirement) in an additional $\$ 37.5$ million in MBS that yield $6.80 \%$. So long as the marginal profit on that $\$ 37.5$ million (i.e., the $6.80 \%$ less the marginal funding cost, times the $\$ 37.5$ million) is greater than the net yield sacrifice on the original \$25 million (i.e., the 20 basis point payment less the likely credit losses, times the $\$ 25$ million), the arbitrage is profitable.
} 
of automobile and credit card lending. This raises the question of how Fannie Mae and Freddie Mac can entice primary market lenders to use their services. The "short answer" is that they are the lowcost providers of liquidity in the secondary conforming mortgage market, due in large part to the implicit federal guarantee of their obligations. As noted by Goodman and Passmore (1992), Fannie Mae and Freddie Mac have: 1) lower operating costs arising from their exemptions from SEC registration requirements and state and local taxes; 2) lower funding costs both in terms of debt issuance and regulatory capital requirements; and 3) the ability to issue AAA-rated credit guarantees generally irrespective of their financial conditions. ${ }^{20}$

The reasons for primary mortgage market lenders to choose to transact with the GSEs largely depend on their type (e.g., insured depository versus uninsured mortgage bank). Differentials in debt financing costs appear to be the primary reason that originators that are not depositories would elect to sell conforming mortgages to Fannie Mae and Freddie Mac. That is, institutions such as mortgage banks are unlikely to be able to obtain as cheaply the finance that would be necessary for holding the mortgages in their own portfolios as can the GSEs. ${ }^{21}$ However, this is less likely to be the case for depository institutions that have access to low-cost debt financing in the form of federally insured deposits. Thus, depository institutions are more likely to use Fannie Mae’s and Freddie Mac's swap programs in order to take advantage of the arbitrage opportunities with respect to their risk-based capital requirements. ${ }^{22}$

\section{Potential Sources of Competition}

\footnotetext{
${ }^{20}$ Furthermore, there is also likely to be economies of scale in securitization and mortgage portfolio management that further reduce unit costs.

${ }^{21}$ Similarly, if the mortgage bank were to decide to try to securitize the conforming mortgages itself, the favored status of the GSEs would place the pricing of the mortgage banks' MBS at a disadvantage.

22 The relative cost efficiency (x-efficiency and/or scale efficiency) of depository institutions, mortgage banks, and the housing GSEs may also play a role.
} 
Various proposals have been floated in recent years with an eye toward increasing competition in the secondary mortgage market, which in turn, would likely also reduce the rates of growth and relative sizes of Fannie Mae and Freddie Mac. For example, Fernandez (2001) discusses proposed legislation that would help Ginnie Mae compete more effectively with Fannie Mae and Freddie Mac. ${ }^{23}$ Another proposal, offered by Stanton (2001), would involve the federal government's chartering numerous national mortgage associations that would compete directly with Fannie Mae and Freddie Mac. Neither of these proposals has gained political traction, and each suffers from its own policy shortcomings.

However, two potential sources of significant competition are emerging as a result of regulatory changes. First, the Federal Home Loan Bank System (FHLB System), another housing GSE, has increasingly been purchasing conforming mortgages from its depository institution members. Second, the likely updated risk-based capital regulations for depository institutions (commonly known as "Basel II") will allow certain large depositories to use internal models to determine required risk-based capital. These new regulations are intended to improve the allocative efficiency of capital and also, on the margin, are likely to increase the mortgage portfolio holdings of participating depository institutions. We will discuss each source of emerging competition in turn.

\section{A. FHLB Mortgage Programs}

The FHLB System is composed of twelve regional wholesale banks that are cooperatively owned by their member financial institutions. ${ }^{24}$ Like Fannie Mae and Freddie Mac, it is a GSE and hence benefits from similar statutory and regulatory exemptions. Historically, the FHLB System

\footnotetext{
${ }^{23}$ Ginnie Mae, or the Government National Mortgage Association, is a government-owned corporation that issues and guarantees MBS backed by mortgage loans guaranteed by the Departments of Housing and Urban Development (HUD) and Veterans Affairs. As of September 30, 2002, Ginnie Mae had over \$568 billion in MBS outstanding.

${ }^{24}$ The twelve FHLBs are located in Atlanta, Boston, Chicago, Cincinnati, Dallas, Des Moines, Indianapolis, New York, Pittsburgh, San Francisco, Seattle, and Topeka.
} 
achieved its housing finance mission by making loans (known as "advances") to its depository institution members secured by residential mortgage loans. These advances are still the primary financial mechanism for the FHLB System. ${ }^{25}$

In 1997, however, the Chicago FHLB began purchasing pools of conforming mortgages in limited quantities under its "mortgage partnership finance" (MPF) program. ${ }^{26}$ In 2000, the Federal Housing Finance Board, the FHLB System's regulator, removed the "pilot status" designation for the MPF program and allowed all twelve FHLBs to purchase mortgages under a new "acquired member assets" rule. $^{27}$ As of late 2003, nine FHLBs offered the MPF program in conjunction with the Chicago FHLB, while the remaining three offered their own "mortgage purchase" (MP) programs. ${ }^{28}$ All of these FHLB mortgage programs use a risk-sharing arrangement whereby members manage most of the credit risk associated with the loans, while the FHLB absorbs the market risk. During 2002, FHLB mortgage purchases totaled \$45.7 billion, and at year-end 2002 there were $\$ 60.6$ billion of these loans outstanding.

The MPF program allows members to sell conventional-conforming ${ }^{29}$ or governmentguaranteed mortgages to their regional FHLB. ${ }^{30}$ In exchange, the member receives payment for the

\footnotetext{
${ }^{25}$ At year-end 2002, the FHLB System had $\$ 490$ billion in advances to members outstanding, which constituted about 64 percent of its assets.

${ }^{26}$ Frame (2003) describes the MPF program in greater detail. Bair (2003) provides a detailed discussion of the policy issues and legal wrangling concerning the introduction of the MPF program.

${ }^{27}$ See Federal Home Loan Bank Acquired Member Assets, Core Mission Activities, Investment, and Advances, 65 Federal Register 43969 (July 17, 2000).

${ }^{28}$ The Federal Home Loan Banks of Cincinnati, Indianapolis, and Seattle operate these MP programs. Additionally, the Federal Home Loan Bank of Atlanta offers both the MPF program and a MP program.

29 "Conventional" mortgage loans are those that are not insured by the Federal Housing Authority (FHA) or the Veterans Administration (VA). The "conforming" loan limits for the FHLB programs are the same as those that apply to Fannie Mae and Freddie Mac's purchases and swaps. However, these limits for the FHLBs are set by regulation and could be changed in the future.

${ }^{30}$ Frame (2003) compares and contrasts the various MPF products.
} 
asset, plus a monthly fee to manage most of the credit risk (typically on the order of 10 basis points annually on the outstanding principal balance). ${ }^{31}$ By contrast, the MP programs do not guarantee credit enhancement income to their seller-members. However, if the loans are still performing after five years, seller-members may receive monthly dividends from a "lender risk account" (described below) based on a predetermined scale. Under all of the FHLB mortgage programs, the FHLB holds the mortgages on its books and hence bears the market risks associated with long-term fixed-rate mortgages, including the funding risk and prepayment risk.

For all FHLB mortgage programs, the credit risk associated with conforming mortgage loans is structured into four layers, or tranches. The approach, similar to that for many "private-label" asset securitizations, involves concentrating the credit risk in lower tranches that are subordinate to the claims of senior tranches. ${ }^{32}$ In all FHLB mortgage programs, the most subordinate tranche (the first-loss position) consists of the homeowner's equity together with any primary mortgage insurance, while the most senior tranche (residual position) is always held by the participating FHLB. ${ }^{33}$ However, there are some differences in the second and third loss positions inherent in the MPF program and the MP programs.

In the MPF program, the seller-member provides the second layer of credit protection in the form of a "first loss account," which is generally set at one percent of the original size of the loan pool. $^{34}$ In the event that the first loss account is exhausted, the seller-member provides the third layer of protection for the FHLB by agreeing to absorb losses up to a pre-specified amount such that

\footnotetext{
${ }^{31}$ Seller-members also receive fee income to service the loans sold to the FHLB. These fees, which are the same as those provided to lenders by Fannie Mae or Freddie Mac, are 25 basis points annually for conventional loans and 44 basis points annually on federally guaranteed loans.

${ }^{32}$ Thus, each lower-level tranche acts as a credit enhancement for all the higher-level tranches.

${ }^{33}$ As with Fannie Mae and Freddie Mac, any loan sold into an FHLB mortgage program is secured by residential real estate and must have either a loan-to-value ratio below 80 percent or else primary mortgage insurance.

${ }^{34}$ Thus, credit losses exceeding the borrower's equity and primary mortgage insurance (if any) accrue to the first loss account and are realized as discounts in the monthly credit enhancement fee paid by the FHLB to its member.
} 
the probability of losses in excess of this layer are no more than those faced by investors in AA-rated securities. ${ }^{35}$ This third layer of protection is often described as the "secondary credit enhancement."

For the MP program, the second layer of protection against losses on mortgage loan pools is a "lender risk account" maintained by the member at the FHLB in an amount of 30-50 basis points of the original loan balance. If the lender risk account is exhausted for a particular mortgage pool, additional losses are covered by a supplemental mortgage insurance policy, which acts as the third layer of protection. The amount of this insurance is set such that probability of losses in excess of the supplemental policy is no more than those faced by investors in AA-rated securities.

By paying credit enhancement fees to seller-members to induce them to bear most of the credit risk, the FHLB mortgage programs essentially place FHLB members in competition with Fannie Mae and Freddie Mac in the mortgage credit guarantee business. This competition can be illustrated by a comparison of the following two alternative scenarios involving an identical pool of residential mortgages:

-- Scenario 1: The FHLB lender-member sells the mortgage pool to its FHLB, retaining the servicing rights and retaining the credit risk.

-- Scenario 2: The same lender sells the same mortgage pool to Fannie Mae (or Freddie Mac) under Fannie Mae’s cash program, but retains the servicing; this sale transfers the credit risk to Fannie Mae. In turn, Fannie Mae issues securities on this mortgage pool, which are bought by the FHLB and for which Fannie Mae retains the credit risk.

In both scenarios the FHLB ends up with the stream of payments on the mortgage pool, on which the FHLB is bearing the market risk. ${ }^{36}$ In the first scenario, however, the lender-member is bearing the credit risk - in essence, guaranteeing the FHLB against credit-risk losses; in the second

\footnotetext{
${ }^{35}$ A software program called LEVELS that is developed by Standard \& Poor's and used by the Chicago FHLB determines these amounts.

${ }^{36}$ The FHLB could, of course, sell or securitize the mortgage pool, so that some third party held the pool and its market risk.
} 
scenario, Fannie Mae is playing that role. These two scenarios demonstrate the potential competition between the lender-member and Fannie Mae (or Freddie Mac) in providing credit guaranties on residential mortgage pools. ${ }^{37}$ The lender's choice will ultimately depends on the credit insurance fees and regulatory capital charges associated with the respective alternatives.

The pricing of mortgage credit guarantees by the MPF program and by Fannie Mae and Freddie Mac is significantly different. On average, Fannie Mae and Freddie Mac charge about 20 basis points annually, while the depository institutions that are participating in the MPF program effectively charge about 10 basis points. But the guarantees are not quite the same. In an MPF transaction the lender-member's liability for credit risk is limited (as is described above), and the FHLBs are absorbing the residual credit risk in the mortgage purchase transactions; ${ }^{38}$ by contrast, Fannie Mae and Freddie Mac provide blanket credit-risk protection on their MBS. Thus, the lendermembers are charging less in the MPF context, but they are also providing a lower quality guarantee.

The FHLB mortgage programs allow their member depository institutions to hold risk-based capital only up to the amount of their actual credit exposure. When it engages in a MPF transaction, a FHLB member is required to hold capital against its secondary credit enhancement, while capital is required against the fair value of the lender risk account in a MP program deal. Like a swap securitization with Fannie Mae or Freddie Mac, the FHLB mortgage programs also allow for regulatory capital arbitrage. For example, using one of the MPF products, a FHLB member could sell the market risk and retain the credit risk and would be required to maintain capital (say, 25 basis points) against its secondary credit enhancement. Using the proceeds of the sale, it could then purchase a mortgage-backed security based on a similar pool of loans and would be required to

\footnotetext{
${ }^{37}$ Also, to the extent that the FHLBs could raise appreciably more funds to hold the mortgage pools in their portfolios, they would become competitors to Fannie Mae and Freddie Mac as holders of mortgage assets; but, as we discuss in the text below, raising more funds may be a problem for the FHLBs.

${ }^{38}$ This credit risk absorption includes the possibility that a FHLB member may become insolvent and default on its secondary credit enhancement obligation to its regional FHLB.
} 
maintain 160 basis points of capital against this asset. In this case, the FHLB member has reassumed both the credit risk and the market risk on a similar pool of loans, but is required to maintain only 185 basis points of regulatory capital, instead of the 400 basis points of capital that is required for a residential mortgage that is held in portfolio. ${ }^{39}$

The FHLB mortgage programs thus appear to offer attractive pricing and regulatory capital treatment for credit risk and have become increasingly popular with members. Nevertheless, it is unclear whether the programs can become significant competitors to Fannie Mae and Freddie Mac because their continued growth will require the FHLBs to restructure their balance sheets either by selling more equity stock to members or by selling assets. Additional stock issuance may not be an attractive option for the FHLBs because: 1) it is considered costly relative to debt issuance; and 2) members are the only eligible purchasers. FHLB asset sales, on the other hand, could take the form of either selling marketable securities held in their portfolio, mortgage assets, or both. While selling securities is straightforward, the selling of mortgage assets has only recently been initiated.

In 2003, the Chicago FHLB began operating a "shared funding program," which allows the institution to acquire collateralized mortgage obligations and sell interests in such assets, but only to other FHLBs or to FHLB System members. The inaugural deals have involved the Chicago FHLB working with certain members to structure securities (shared funding certificates) that are backed by conventional-conforming mortgages, using a REMIC structure. In the first deals, certain FHLBs have purchased senior tranches (AAA or AA-rated), while FHLB members have acquired the subordinate tranches. ${ }^{40}$ While the first shared funding transactions didn't actually involve the Chicago FHLB shedding assets, the program does allow for it through the sale of shared funding

\footnotetext{
${ }^{39}$ This does not represent an exact replication because the FHLB would still retain the residual credit risk on the first mortgage pool, for which it is subject to a credit risk-based capital charge of 37 basis points.

${ }^{40}$ Thus, like the other FHLB mortgage programs, the shared funding program allows a FHLB to take on market risk through its purchase of the senior securities, while the member retains most of the credit risk through the subordinated securities. However, two important distinctions are: 1 ) the member retains some market risk by holding the subordinate securities; and 2) liquidity may be improved by holding the mortgage pool in the form of a marketable security.
} 
certificates. $^{41}$

As demonstrated above, the FHLB mortgage programs provide incentives for lendermembers to retain mortgage credit risk, while selling the attendant market risk to the FHLB System. While this clearly represents a competitive threat to Fannie Mae’s and Freddie Mac's credit guarantee business, it may also affect their retained mortgage portfolio. That is, the market risk associated with MPF and MP assets will reside with the FHLBs, with their members, and/or with anyone to whom the members sell their shared funding certificates. To the extent that these assets would otherwise have been sold to Fannie Mae or Freddie Mac, ${ }^{42}$ increased usage of FHLB mortgage programs may also serve to stem the growth of the retained portfolios of Fannie Mae and Freddie Mac.

\section{B. Basel II}

U.S. commercial banks are required to meet two minimum capital requirements to be considered “adequately capitalized”: 1) a minimum leverage ratio, which is a ratio of Tier 1 capital to total assets of four percent; and 2) a total risk-based capital ratio, which is total capital to riskweighted assets of eight percent. ${ }^{43}$ The latter requirement, which is a product of the original 1988

\footnotetext{
${ }^{41}$ Though current regulations restrict the FHLBs' sale of shared funding certificates to other FHLBs or to FHLB System members, there are no restrictions on the members' ability to resell the certificates to the general public; or the FHLBs may receive authority in the future to make such sales directly to the public.

${ }^{42}$ For example, if FHLB System members are required to hold only 1.6\% capital against their holding of shared funding certificates, this “regulatory arbitrage” will increase members' incentives to hold mortgage assets in this form.

${ }^{43}$ In practice, many banks hold capital exceeding a minimum leverage requirement to be considered "adequately capitalized." Indeed, to be "well capitalized, a bank would have to: 1) hold five percent Tier 1 capital to total assets, and 2) hold ten percent total capital to risk-adjusted assets. The federal banking agencies (Federal Reserve Board, Office of the Comptroller of the Currency, and Federal Deposit Insurance Corporation) define total capital as the sum of Tier 1 and Tier 2 capital. Tier 1 capital includes common shareholders' equity (stock and retained earnings), noncumulative, perpetual preferred stock, and minority interests in the equity accounts of consolidated subsidiaries. Tier 2 capital includes cumulative perpetual preferred stock, long-term preferred stock, convertible preferred stock, and hybrid instruments combining debt and equity features. Tier 2 also includes limited amounts each of allowances for loan and lease losses, subordinated debt, intermediate preferred stock, and unrealized gains on equity securities. Various eligibility criteria apply to several Tier 2 components. Deductions from capital include goodwill assets and other
} 
Basel Capital Accord (Basel I), assigns risk-weights to various asset classes. As mentioned above, among mortgage-related assets, single-family residential loans are assigned a 50 percent risk weight (i.e., a total required capital of 4.0 percent), while AA-rated (or better) mortgage backed securities are weighted at 20 percent (total required capital of 1.6 percent). ${ }^{44}$

The Basel Committee on Banking Supervision is in the process of implementing a new international capital accord, commonly known as Basel II, which is intended to improve the alignment of capital and risk and hence reduce the propensity for depository institutions to engage in regulatory capital arbitrage. ${ }^{45}$ The federal banking agencies have issued an "advanced notice of proposed rulemaking" (ANPR) that suggests that only banks with significant foreign exposures would be subject to the new rules -- all under the "advanced internal ratings based approach." ${ }^{46}$ However, any bank that meets the infrastructure requirements of this approach could elect to be subject to Basel II. According to Ferguson (2003), it appears that only 10 of the largest U.S. banks will initially be subject to the new capital rules, with about another 10 expected to "opt-in"; but these 20 large banks account for two-thirds of all domestic banking assets held by U.S. banks. More important for the purposes at hand, according to our calculations, the 20 largest U.S. bank and thrift

intangibles and investments in certain subsidiaries. Precise definitions can be found at: 12 C.F.R. Part 208, Appendix A (Federal Reserve Board), 12 C.F.R. Part 3, Appendix A (Office of the Comptroller of the Currency), and 12 C.F.R. Part 325, Appendix A (Federal Deposit Insurance Corporation)

${ }^{44}$ According to Calem and LaCour-Little (forthcoming), the 50 percent weighting for whole mortgages has been assigned to prudently underwritten, performing, prime credit quality loans that either have loan-to-value ratios below 90 percent or private mortgage insurance. Residential mortgages not meeting these criteria fall into the 100 percent risk weight category.

${ }^{45}$ Both Basel I and Basel II focus on credit risk in assigning risk weights, although Basel II also imposes operations risk charges. Neither initiative involves explicit charges for interest rate or other market risks, which are evaluated in the context of the supervisory process. An exception to this is assets held in trading accounts and foreign exchange and commodity exposures.

${ }^{46}$ The ANPR is published at 68 Federal Register 45900 and is also available at www.federalreserve.gov/boarddocs/press/bcreg/2003/20030804/attachment.pdf. The Basel II proposal includes three different approaches: 1) the standardized approach, 2) the foundation internal ratings based approach, and 3) the advanced internal ratings based approach. See Basel Committee (2003a); see also the Basel Committee's web site, www.bis.org, for a number of consultative papers that provide both background and technical details related to Basel II. 
companies $^{47}$ held almost $\$ 946$ billion in 1-4 family residential mortgage loans and $\$ 415$ billion in residential mortgage-backed securities on their books at year-end 2002. Together, this accounted for just over half (50.7 percent) of the industry total of 1-4 family mortgage-related assets.

The proposed treatment of residential mortgages under Basel II's "advanced internal ratings based approach" requires estimates, derived from statistical models, of the probability of default (PD), loss given default (LGD), exposure at default (EAD), and asset correlation (R) for pools of these loans. These estimates are used, in turn, to construct capital charges as a percent of assets (K) in a value-at-risk framework (using the 99.9 percent confidence interval) using the following equation:

$$
\mathrm{K}=\mathrm{LGD} * N\left[(1-\mathrm{R})^{-0.5} * G(\mathrm{PD})+\left(\mathrm{R} *(1-\mathrm{R})^{-0.5} * G(0.999)\right]\right.
$$

where $N$ denotes the standard normal cumulative distribution function and $G$ its inverse. ${ }^{48}$ The ANPR sets floors for both PD (0.03 percent) and LGD (10 percent) that will be subject to periodic review. The proposal also requires an assumption that $\mathrm{R}$ is 15 percent. $^{49}$ It's worth pointing out that the Basel II capital charges generated by equation (1) are determined solely by measured credit risk and do not include a capital charge for interest rate risk.

It is widely accepted that the Basle I credit risk-based capital requirement of 4.0 percent for prime residential mortgages is too high relative to these assets' risks and that this excessively high capital requirement has created an incentive for U.S. depository institutions to swap these mortgages for MBSs issued by Fannie Mae and Freddie Mac. To the extent that Basel II allows

\footnotetext{
${ }^{47}$ Assets of insured depository institutions controlled by the same company were combined to determine this ranking. Arguably, if the lead bank will operate subject to Basel II, its affiliated banks will as well.

${ }^{48}$ Total required capital in dollar terms could then be calculated by multiplying equation (1) by the estimated exposure at default, or EAD.

${ }^{49}$ See Calem and Follain (2003) for further discussion of the asset correlation parameter and how it is estimated.
} 
banks to hold regulatory capital that is more commensurate with the economic risk of loss, it should reduce their incentives to engage in regulatory capital arbitrage and increase their incentives to retain residential mortgages as unsecuritized whole loans on their balance sheets. However, the extent to which this will occur is dependent on the amount of capital savings.

Empirical evidence suggests a significant reduction in risk-based capital requirements for residential mortgages. Calem and LaCour-Little (forthcoming) and Calem and Follain (2003) report economic capital estimates from a model developed by Federal Reserve Board staff using transition probabilities from the Loan Performance Risk Model and simulations of future house prices and interest rates. For a nationally diversified portfolio of 30-year fixed-rate mortgages, these studies uncover a range of required capital from roughly 20 to 400 basis points ( 0.2 to 4.0 percent), depending on the original loan-to-value of the mortgage and the borrowers' credit scores. Broader estimates of changes in required capital for residential mortgages are presented in Basel Committee (2003b). That study, based on a small number of large internationally active banks from around the world, estimated an average reduction in required capital for residential mortgage portfolios under the "advanced internal ratings based approach" at about 60 percent. This implies a 1.6 percent average proportion of required capital to total mortgage assets.

At first blush, since risk-based capital requirements for mortgages are well below the minimum leverage requirements, that there should be little market impact from Basel II. However, to the extent that depository institutions hold a diversified loan portfolio that includes higher-risk loans that require capital levels that are above the minimum leverage requirements, they would be able to balance, say, their low-capital mortgage loans with their higher-capital commercial loans. So, at the margin, these institutions could allocate to residential mortgages the lower levels of capital that Basel II would permit, and their pricing behavior (i.e., the interest rates at which they would be willing to originate and hold these mortgages) would reflect these lower capital levels. ${ }^{50}$

\footnotetext{
50 This point, in turn, raises the question of how a large depository institution specializing in residential mortgage lending, for which the leverage ratios will be the binding constraint, will be able to compete for mortgages with
} 
If Basel II is adopted, bank’s operating under this new risk-based capital regime will likely have an increased incentive to retain whole mortgages. And like the FHLB mortgage programs, Basel II represents a competitive threat to the growth of both Fannie Mae's and Freddie Mac's credit guarantee business, as well as their retained mortgage portfolios.

\section{The Effect on Risk-Taking Incentives}

The discussion above suggests that the two categories of depository institutions that have been analyzed -- members of the FHLB System and large banks operating under Basel II - are likely to benefit from reduced capital charges for holding mortgage loans directly on their balance sheets (under Basel II), for holding mortgage credit risk (through the FHLB System's MPF and MP programs), and for holding the market risk of mortgages through holding the FHLB System's shared funding certificates. These changed incentives are likely to increase these institutions' retention of mortgage assets, directly or indirectly. This development, in turn, is likely to increase competition in the secondary conforming mortgage market, narrow the spreads that Fannie Mae and Freddie Mac can earn on their retained portfolios, and reduce the demand for (and the prices of) Fannie Mae and Freddie Mac credit guarantees. Ultimately, this should increase the transmission of GSE benefits and reduce mortgage interest rates paid by borrowers. ${ }^{51}$ But this same increase in competition may also affect the GSEs' risk-taking incentives.

All three housing GSEs accrue federal benefits through the market's perception of a federal guarantee of their debt and MBS obligations. This belief in the high likelihood of being "bailed out," in turn, means that the GSEs' creditors engage in less monitoring and exercise less restraint -

diversified lenders.

${ }^{51}$ As White (2003) points out, however, this reduced interest rate for borrowers will exacerbate the problem of the excessive consumption of housing services that U.S. policies already encourage. This is, of course, another demonstration of the Lipsey and Lancaster (1956) insight that in a world of second-best, one cannot automatically assume that an apparent improvement in the efficiency of one aspect of a market will improve overall welfare. 
i.e., impose less "market discipline" -- over the GSEs' activities (including their levels of capital) than would be true if the creditors believed themselves to be at risk. And this reduced monitoring and restraint would then (unless the GSEs are otherwise restrained by government safety-andsoundness regulation) lead to "moral hazard" on the part of their owners or of senior management acting on the owners' behalf. That is, the legal institution of limited liability for owners would lead to excessive risk-taking at the expense of creditors, because the owners get the "upside" but are limited in their exposure to the "downside", which is absorbed by the creditors (or the creditors' guarantor) after the owners' stake is exhausted. Equivalently, the GSEs would maintain insufficient capital for the levels of risk undertaken. ${ }^{52}$

However, to the extent that the benefits are accompanied by barriers to entry and reduce competition in a particular product market, they provide firms with "franchise value," or positive expected economic profits. ${ }^{53}$ Firms with franchise value effectively have more capital at risk than the nominal book value of their capital that is shown on their balance sheets. Since greater levels of capital reduce the incentive to engage in risky behavior (the owners have more to lose in the event of "downside" outcomes), firms with more franchise value will likely engage in lesser levels of risky behavior. Conversely, erosions in franchise value will (other things being equal) lead to more risky behavior. $^{54}$

\footnotetext{
${ }^{52}$ This problem of moral hazard is, of course, a general problem for the creditors of limited liability corporations. Outside of the financial sector, creditors long ago realized the existence of the problem and created monitoring structures as well as lending agreements and indentures in bonds that give the creditors the powers to restrain owners and managers in certain situations, especially when capital (net worth) levels diminish. Because bank creditors (primarily depositors) have been thought less capable of monitoring and protecting themselves against this moral hazard behavior, and because the consequences of bank insolvency failures have been considered economically serious (e.g., the potential problem of contagion) and politically serious (the personal losses experienced by individual depositors), banks and other depositories have long been subject to governmental safety-and-soundness regulation, which serves as a substitute for the private monitoring just described.

${ }^{53}$ For example, the federal charters of Fannie Mae and Freddie Mac are unique, and the Congress is unlikely to charter "clones" of the two GSEs.

${ }^{54}$ See, for example, Keeley (1990), Demsetz, Saidenberg, and Strahan (1996), and Saunders and Wilson (2001) for a more complete discussion of the disciplinary role of franchise value in financial services. For a dissenting view, see Boyd and De Nicolo (2003).
} 
It is clear that Fannie Mae and Freddie Mac do enjoy substantial levels of franchise value. The franchise values (as proxied by year-end ratios of the market value of common equity to its book value ${ }^{55}$ ) of Fannie Mae, Freddie Mac, and (for comparison) the average of the 10 largest U.S. commercial bank holding companies (BHCs) for the 1990-2002 period are presented in Figure $1 .^{56}$ As can be seen, Fannie Mae and Freddie Mac have had and continue to have franchise value ratios considerably exceeding 1.0. Further, it is striking that, except for the sharp decline in Freddie Mac's franchise value ratio in 2002, ${ }^{57}$ the two GSEs' franchise value ratios have been substantially above the average for the BHCs. Also, the general trends over time for the two GSEs and the BHCs have been roughly similar, suggesting that a common factor (e.g., interest rates) has been an influence on these trends.

Increased competition from the FHLB mortgage programs and large banks operating under Basel II is likely to reduce Fannie Mae’s and Freddie Mac's expected profits (returns) and hence their franchise values. As a result, these enterprises will have less effective capital at stake and may well be inclined to undertake more risky behavior. ${ }^{58}$ In essence, Fannie Mae and Freddie Mac will be faced with the choice of either accepting these lower expected returns or taking on more risk so as to try to regain some or all of their lost returns.

\footnotetext{
${ }^{55}$ To the extent that franchise value is an inhibition on risk-taking, it is the ratio that should matter; i.e., a million dollars in franchise value will have a much greater incentive effect on an institution with $\$ 5$ million in book value of capital than on an institution with $\$ 50$ million in book value of capital.

${ }^{56}$ The data are drawn from COMPUSTAT data files and from U.S. Office of Federal Housing Enterprise Oversight (2003a). Data for the BHCs is for the 10 largest institutions in each year (as opposed to selecting the 10 largest as of 1990 and following them forward).

${ }^{57}$ The sharp fall in Freddie Mac's relative franchise value at the end of 2002 was partly driven by a modest drop in the company's share price (perhaps in anticipation of the accounting and managerial difficulties that followed in 2003) and a substantial increase in the book value of shareholders' equity.

${ }^{58}$ This (inverse) linking of market power and risk is somewhat different from that envisaged by Hicks (1935), who remarked: "The best of all monopoly profits is a quiet life." For Hicks, the link was through the sheltering from competition that a monopolist enjoys and the ability of the monopolist to trade off lower profits in return for reduced uncertainty. By contrast, the link envisaged here operates through the risk-taking incentives that accompany the reduced effective capital of lower monopoly rents.
} 
As safety-and-soundness regulator, OFHEO actively monitors the risk positions of Fannie Mae and Freddie Mac, while the U. S. Department of Housing and Urban Development is responsible for the approval of any new programs offered by these enterprises. ${ }^{59}$ These regulators will need to be aware of the effect of increased competition on the risk-taking incentives of Fannie Mae and Freddie Mac. OFHEO’s forward-looking risk-based capital “stress test” should presumably identify any obvious increase in the riskiness of Fannie Mae’s and Freddie Mac's activities that occurs in response to heightened competition, and OFHEO would then require additional capital. Nevertheless, it is widely recognized that capital requirements can be "gamed" so as to allow the regulated entity to take on more risk than the standards are intended to permit. ${ }^{60}$ Indeed, an important justification for the use of leverage ratios is regulators' fears that risk-based capital requirements can be gamed in poorly understood or unknown ways. Incentives for such gaming will likely increase with the levels of competition that Fannie Mae and Freddie Mac will face, and it is these incentives that warrant heightened regulatory attention and awareness.

\section{Conclusions}

The presence and purpose of Fannie Mae and Freddie Mac continue to be a major point of policy contention. This paper describes two likely sources of increased competition for these two GSEs: the mortgage programs of the Federal Home Loan Bank System, and the revised (Basel II) capital requirements that will apply to large U.S. depositories. Greater competition in the primary and secondary mortgage markets will be beneficial for borrowers and will likely reduce the relative size and importance of Fannie Mae and Freddie Mac. However, this competition would also erode these GSEs' franchise values and hence effective capital. This, in turn, could result in Fannie Mae

\footnotetext{
${ }^{59}$ As this paper is being written, the Congress is considering the transfer of federal safety-and-soundness regulatory authority over Fannie Mae and Freddie Mac from OFHEO to a new agency that would be situated within the Treasury Department. See Frame and White (2004) for a detailed discussion.

${ }^{60}$ The “capital arbitrage” examples that we discussed above are instances of such gaming.
} 
and Freddie Mac engaging in riskier behavior, unless restrained by safety-and-soundness regulation. How this competitive landscape evolves warrants heightened regulatory awareness. 


\section{References}

Ambrose, Brent W. and Arthur Warga. 1996. Implications of privatization: the costs to Fannie Mae and Freddie Mac. In U.S. Department of Housing and Urban Development, Studies on Privatizing Fannie Mae and Freddie Mac. Washington, D.C.: HUD: 169-204.

Ambrose, Brent, and Arthur Warga. 2001. Measuring potential GSE funding advantages. Journal of Real Estate Finance and Economics 25(2/3): 129-150.

Bain, Joe. 1956. Barriers to New Competition. Cambridge, MA: Harvard University Press.

Bair, Sheila, 2003. Is the Federal Home Loan Bank System forsaking its roots? Mimeo. University of Massachusetts-Amherst. Available at www.fanniemae.com/commentary/pdf/071403.pdf.

Basel Committee on Banking Supervision. 2003a. Overview of the new Basel capital accord. Basel: Bank for International Settlements.

Basel Committee on Banking Supervision. 2003b. Quantitative Impact Study 3 - Overview of Global Results. Basel: Bank for International Settlements.

Boyd, John H. and Gianni De Nicolo. 2003. Bank risk taking and competition revisited. IMF Working Paper WP/03/114, May. Available at www.imf.org/external/pubs/ft/wp/2003/wp03114.pdf.

Calomiris, Charles W. 2001. An economist's case for GSE reform. In Serving Two Masters yet out of Control: Fannie Mae and Freddie Mac, edited by Peter J. Wallison. Washington, D.C.: AEI Press.

Calem, Paul and Michael LaCour-Little. forthcoming. Risk-based capital requirements for mortgage loans. Journal of Banking and Finance.

Calem, Paul and James Follain. 2003. The asset correlation parameter in Basel II for mortgages on single-family residences. Mimeo, Federal Reserve Board. Available at www.federalreserve.gov/generalinfo/basel2/docs2003/asset-correlation.pdf.

Cotterman, Robert F. and James E. Pearce. 1996. The effects of the Federal National Mortgage Association and the Federal Home Loan Mortgage Corporation on conventional fixed-rate mortgage yields. In U.S. Department of Housing and Urban Development, Studies on Privatizing Fannie Mae and Freddie Mac. Washington, D.C.: HUD: 97-168.

Demsetz, Rebecca S., Marc R. Saidenberg, and Philip E. Strahan. 1996. Banks with something to lose: The disciplinary role of franchise value. Federal Reserve Bank of New York Economic Policy Review 2 (October): 1-14. 
Fahey, Noel. 2003. Systemic risk: A Fannie Mae perspective. Fannie Mae Papers II(2). Available at: http://www.fanniemae.com/commentary/pdf/fmpv2i2.pdf.

Fannie Mae, 2001. Setting the record straight: An analysis of CBO's 2001 report on Fannie Mae and Freddie Mac. May 23, 2001. Available at www.fanniemae.com/global/pdf/ir/issues/fmcbo.pdf.

Fannie Mae, 1996. Fannie Mae review of the Hermalin-Jaffee paper. In Studies on Privatizing Fannie Mae and Freddie Mac. Washington, D.C.: HUD: 314-332.

Feldman, Ronald. 2002. Mortgage rates, homeownership rates, and government-sponsored enterprises. Federal Reserve Bank of Minneapolis The Region 16(1): 4-24.

Ferguson, Roger, 2003. Testimony before the U.S. Senate Committee on Banking, Housing, and Urban Affairs, June 18.

Fernandez, Tommy. 2001. Move to let Ginnie rival big cousins. American Banker, November 5.

Frame, W. Scott. 2003. Federal Home Loan Bank mortgage purchases: Implications for mortgage markets. Federal Reserve Bank of Atlanta Economic Review 88 (third quarter): 17-31.

Frame, W. Scott and Larry Wall. 2002. Financing housing through government-sponsored enterprises. Federal Reserve Bank of Atlanta Economic Review 87 (first quarter): 29-43.

Frame, W. Scott and Lawrence J. White. 2004. Regulating housing GSEs: Thoughts on institutional structure and design (forthcoming).

Freddie Mac, 2001. Detailed Analysis of the 2001 CBO Report Federal Subsidies and the Housing GSEs. Appendix to the written statement of Mitchell Delk before the U.S. House of Representatives Subcommittee on Capital Markets, Insurance, and Government-Sponsored Enterprises (Committee on Financial Services), July 11. Available at www.freddiemac.com/speeches/md071101.htm (February 6, 2002).

Goodman, John L. and S. Wayne Passmore. 1992. Market power and the pricing or mortgage securitization. Federal Reserve Board's Finance and Economics Discussion Series, Number 187.

Hermalin, Benjamin, and Dwight Jaffee. 1996. The privatization of Fannie Mae and Freddie Mac: Implications for mortgage industry structure. In Studies on Privatizing Fannie Mae and Freddie Mac. Washington, D.C.: HUD: 225-302.

Hendershott, Patric H., and James D. Shilling. 1989. The impact of agencies on conventional fixedrate mortgage yields. Journal of Real Estate Finance and Economics 2 (June): 101-115. 
Hicks, J.R. 1935. Annual survey of economic theory: The theory of monopoly. Econometrica 3 (January): 1-20.

Inside Mortgage Finance. 2003a. The 2003 Mortgage Market Statistical Annual, Volume I: The Primary Mortgage Market. Bethesda, MD: Inside Mortgage Finance Publications, Inc.

Inside Mortgage Finance. 2003b. The 2003 Mortgage Market Statistical Annual, Volume II: The Secondary Mortgage Market. Bethesda, MD: Inside Mortgage Finance Publications, Inc.

Jones, David. 2000. Emerging problems with the Basel capital accord: Regulatory capital arbitrage and related issues. Journal of Banking and Finance 24: 35-58.

Kane, Edward J., and Chester Foster. 1986. Valuing conjectural government guarantees of FNMA liabilities. In Proceedings: Conference on Bank Structure and Competition. Chicago: Federal Reserve Bank of Chicago.

Keeley, Michael C. 1990. Deposit insurance, risk, and market power in banking. American Economic Review 80 (December): 1183-1200.

Lipsey, R.G. and K. Lancaster. 1956-1957. The general theory of the second best. Review of Economic Studies 24: 11-32.

McKenzie, Joseph. 2002. A reconsideration of the jumbo/non-jumbo mortgage rate differential. Journal of Real Estate Finance and Economics. 25: 197-213.

Mills, Edwin S. 1987. Dividing up the investment pie: Have we overinvested in housing? Federal Reserve Bank of Philadelphia Business Review (March/April): 13-23.

Pearce, James E. and James C Miller III, 2001. Response to CBO's draft report: Federal Subsidies and Housing GSEs. Freddie Mac Press Release issued May 18, 2001. Available at www.freddiemac.com/news/analysis/gse_benefits2.htm.

Roll, Richard. 2003. Benefits to homeowners from mortgage portfolios retained by Fannie Mae and Freddie Mac. Journal of Financial Services Research 23 (February): 29-42.

Saunders, Anthony, and Berry Wilson. 2001. An analysis of bank charter value and its riskconstraining incentives. Journal of Financial Services Research 19 (April/June): 185-95.

Stanton, Thomas H.. 2001. An alternative approach to GSE reform through national mortgage associations. In Serving Two Masters yet out of Control: Fannie Mae and Freddie Mac, edited by Peter J. Wallison. Washington, D.C.: AEI Press.

Taylor, Lori L. 1998. Does the United States still overinvest in housing? Federal Reserve Bank of 
Dallas Economic Review (Second Quarter): 10-18.

Tirole, Jean. 1988. The Theory of Industrial Organization. Cambridge, MA: MIT Press.

Toevs, Alden 2001. Federal subsidies and the government-sponsored enterprises: An analysis of the CBO study. Bank Accounting and Finance 15(1): 24-31.

U.S. Congressional Budget Office. 1996. Assessing the Public Costs and Benefits of Fannie Mae and Freddie Mac. Washington, D.C.: CBO.

—. 2001. Federal Subsidies and the Housing GSEs. Washington, D.C.: CBO.

U.S. Department of the Treasury. 1996. Government Sponsorship of the Federal National Mortgage Association and the Federal Home Loan Mortgage Corporation. Washington, D.C.: Treasury.

U.S. General Accounting Office. 1990. Government-Sponsored Enterprises: The Government's Exposure to Risks. Washington, D.C.: GAO.

1996. Housing Enterprises: Potential Impacts of Severing Government Sponsorship (GAO/GGDS 96-120). Washington, D.C.: GAO.

U.S. Office of Federal Housing Oversight (OFHEO). 2003a. Report to Congress. Washington, D.C.: OFHEO.

- 2003b. Systemic Risk: Fannie Mae, Freddie Mac and the Role of OFHEO. Washington, D.C.: OFHEO.

Van Order, Robert. 2000a. A microeconomic analysis of Fannie Mae and Freddie Mac. Regulation 23(2): 27-33.

Van Order, Robert. 2000b. The U.S. mortgage market: a model of dueling charters. Journal of Housing Research 11(2): 233-255.

Van Order, Robert. 2001. The economics of Fannie Mae and Freddie Mac, in Peter J. Wallison, ed., Serving Two Masters, Yet Out of Control: Fannie Mae and Freddie Mac. Washington, D.C.: AEI Press: 41-54.

Weicher, John C. 1994. The new structure of the housing finance system. Federal Reserve Bank of St. Louis Review, 76 (July/August): 47-65.

White, Lawrence J. 1996. Comments on the Hermalin-Jaffee paper. In Studies on Privatizing Fannie Mae and Freddie Mac. Washington, D.C.: HUD: 305-313. 
White, Lawrence J., 2003. Focusing on Fannie and Freddie: The dilemmas of reforming housing finance. Journal of Financial Services Research, 23 (February): 43-58.

Woodward, Susan E. 2001. Rechartering Fannie Mae and Freddie Mac: The policy issues. mimeo, Sand Hill Econometrics, Menlo Park, CA. 
Figure 1: Franchise Value (market/book of common equity), 1990-2002

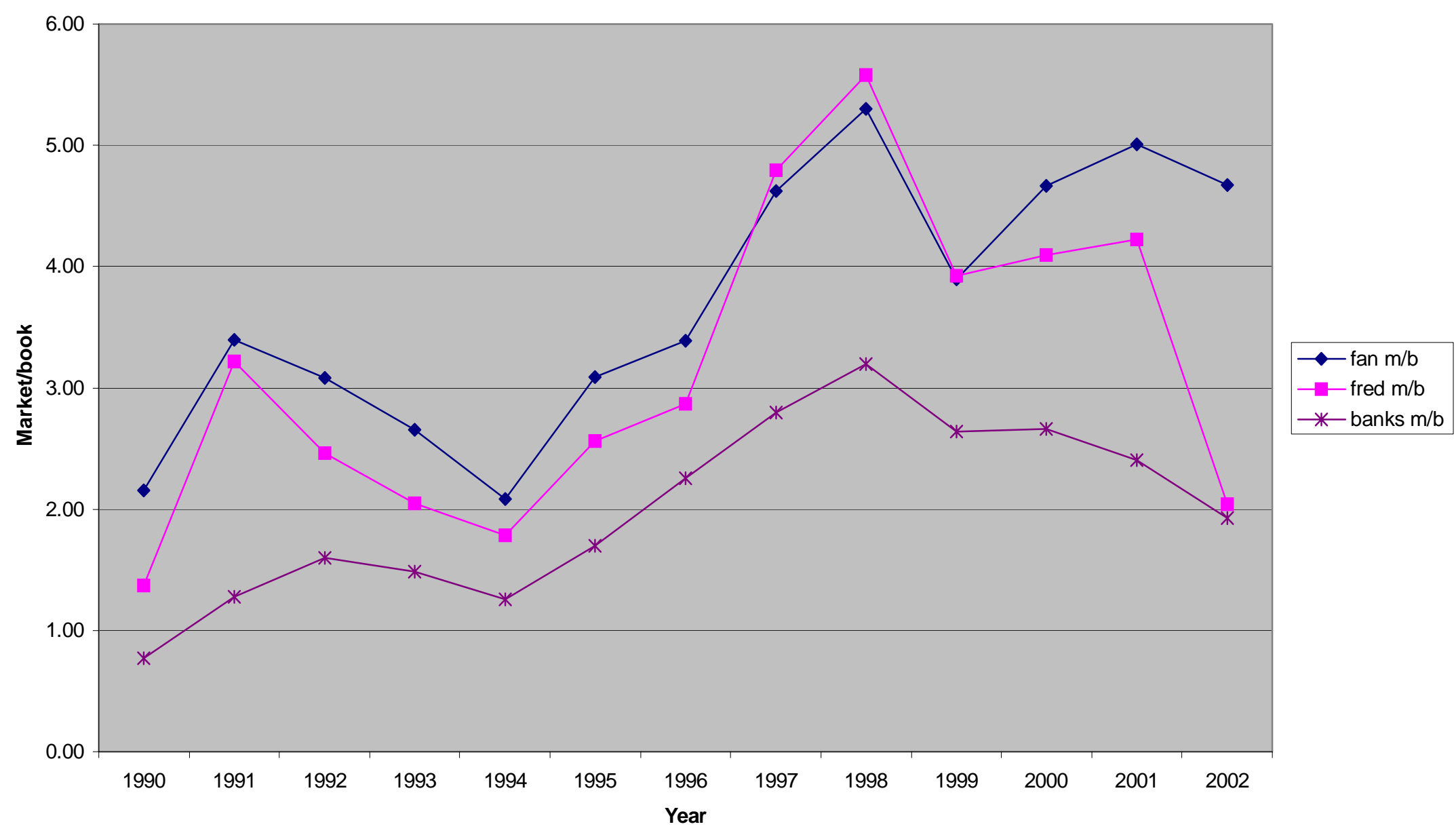

